\title{
Satellite delay adds to Italy's space blues
}

Munich. The launch of the high-resolution X-ray telescope XMM, one of the four 'cornerstone' missions of the European Space Agency's science programme, is likely to be delayed by at least a year if ESA adopts a proposal to ask for new bids for the project's main management contract.

This follows criticism by ESA officials of a tender for the ECU280 million contract to design and build the XMM - originally planned for launch in 1998 or 1999 which had been submitted by a consortium of European companies headed by Italy's main space contractor Alenia Spazio.

The ESA executive has agreed that the tender is technically acceptable, but deemed it unacceptable on grounds of both cost and the proposed programme management. As a result, it has recommended to the ESA industrial policy committee, which meets next week (14 March), that the whole programme be put out again for tender

Alenia is refusing to make any public comment on the affair. But the decision is a new blow to Italy's space community, whose role in ESA has already been weakened by the country's general political and economic difficulties, as well as by charges of corruption against the Italian Space Agency (ASI).

Italy seems to have promised in recent years a higher level of participation in ESA programmes than the country now finds it can afford. Such overcommitments, combined with last year's devaluation of the lire, mean that Italy is already having difficulty in paying its membership fees to ESA, which this year come to ECU370 million.

After discussions earlier this year with Umberto Colombo, the minister for research and universities, ESA has agreed to conmillion to cover the expected deficits in Italy's contributions to the agency over the sider taking out a loan of up to US\$100 next few years. This procedure, although unusual, is not unprecedented, and Colombo has promised that the loan would be paid back in 1996 and 1997, when he expects Italy's beleaguered space programme to be back on the rails.

Meanwhile, Colombo has proposed a new board for ASI, which is currently under criminal investigation for mismanagement of funds. The board will be headed by Giorgio Fiocco, an atmospheric physicist, and will take over from a temporary management team put in charge last September to sort out the chaos in the agency.

If approved by Parliament, the proposed board offers a relatively fresh start for ASI only one of its twelve members has served before. Parliament has until 15 March to raise objections; otherwise the board will automatically be approved. The timing of the announcement, made when Parliament is not sitting because of election campaigning, means that the board is likely to be approved by default.

Whatever the outcome, ASI's troubles continue. On Monday 28 February, police confiscated files from the agency in preparation for a criminal investigation into the alleged mismanagement of billions of lire.

Alison Abbott

\section{Bulgarian strike lifts science budget}

Munich. A two week "symbolic strike" by Bulgarian scientists, in which the scientists turned up at their laboratories but did not carry out any work, resulted in partial victory last week when the government agreed to increase this year's budget for the Academy of Sciences by over six per cent.

But the government is still rejecting the scientists' second demand, namely a new science law which would establish a science policy agenda with a guaranteed level of financial support.

Last year around, 700 million leva was allocated to the Bulgarian Academy of Sciences to run its 75 research institutes, comprising over 10,000 staff (of which 4,300 are scientists). Because of the government's financial difficulties, however, only 642 million leva were in fact distributed, barely enough to keep the institutes alive. (All subscriptions to foreign journals, for example, were stopped last year).

The situation was made worse by the

\section{Elephantine egg heads for the hammer}

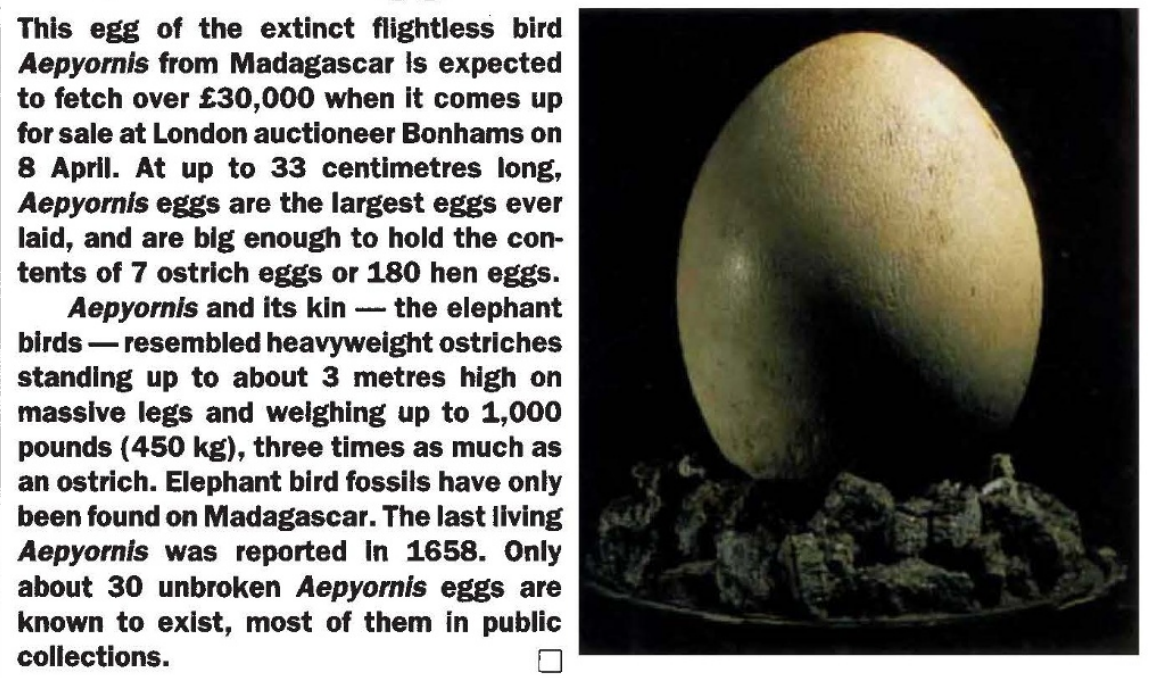

announcement last December that a new technocrat government installed by the Bulgarian president at the end of 1992 planned to give the academy only 930 million leva (US\$23 million) this year. With inflation running at nearly 50 per cent, this would have meant a considerable fall in funding in real terms.

The announcement initiated a campaign last December by the Academy of Sciences for more money and for a national science policy which would establish science as a priority for the country's economic recovery. The campaign culminated in the strike, which started on 14 February. The government ended the strike two week's later by offering an additional 60 million leva to the academy's budget.

The scientists' strike came on top of a much longer strike by university students, which began in late January, for more money for education. This strike was also called off last week because students decided to sit their winter semester exams.

The government has, however, agreed to improve the welfare and living conditions for students from the countryside. Since the 1970 s, foreign students had been given priority treatment on issues such as housing in the nation's capital, Sofia, to the cost of Bulgaria's own students.

Naum Yakimoff, general secretary of the Academy of Sciences, says that neither the scientists' nor the students' strikes were entirely about money. Equally important, he says, is the need for science to be given its proper recognition if the country is to pull itself out of its dire economic situation.

Yakimoff is continuing to press for a law defining a science policy for Bulgaria, which would include a guarantee of a minimal level of financial support pegged to the country's gross national project (GNP). $\mathrm{He}$ would like to see Bulgaria spend 2 per cent of GNP on science.

Alison Abbott 